\title{
Using Apple (Malus domestica), Pumpkin (Cucurbita maxima) and Cinnamon (Cinnamom vertum) to Obtain an Innovative Jam-Like Food Product
}

\author{
Maria Lidia IANCU* \\ Faculty of Agricultural Sciences, Food Industry and Environmental Protection "Lucian Blaga" University \\ from Sibiu, 5-7, Ion Rațiu Street, Sibiu, 550012 Sibiu, România \\ *corresponding author: maria.iancu@ulbsibiu.ro
}

Bulletin USAMV series Agriculture 74(2)/2017

Print ISSN 1843-5246; Electronic ISSN 1843-5386

DOI 10.15835/buasvmcn-agr: 0019

\begin{abstract}
The apple, the pumpkin and the cinnamon are raw materials that could be innovatively combined to produce a new sugar-preserved product following an original recipe. It can be considered in accordance with the European quality of jam-type varieties. It is a hybrid product, a component of "the European gastronomy" with old Bavarian roots and Romanian raw material. An adapted technological scheme and a recipe based on the TSS of the raw material and of the finished product were used. The quality indicators were determined using analytical methods. The PCA with the results provided by the panelists were used for the study of the aromatic profile. An identification of flavors, such as apple and cinnamon, is reported, which contributes to the specificity of the sensory profile of the jam. The new product has: $\mathrm{TSS}=63.6^{\circ} \mathrm{Brix}, \mathrm{TA}=0.2 \%, \mathrm{VA}=0.105 \%$. These values fall within the range of values for other jam and experimental jam assortments. The proportion of solids is $34 \%$, which is far too low compared to the $45 \%$ minimum accepted limit. Taking into account that there is no "surface lifting" flaw, it is recommended to accept the value for the new assortment.
\end{abstract}

Keywords: apple, pumpkin, cinnamom, jam processing aromatic profile

\section{INTRODUCTION}

At present, there is considerable demand for fruit and vegetables, as they are considered rich sources of nutrients beneficial to human health (Yahia, 2010). If they cannot be all eaten fresh, they can be preserved. One method to preserve them is to use the anabiosis - physio - anabiosis as the biological preservative principle and the osmoanabiosis, sugar preservation, more specifically the preparation of jam, as procedure.

Jam is defined as a food product, slightly concentrated and consistent, which is obtained by moistening in sugar certain morphological parts of the plants (whole fruit or split into $1-2 \mathrm{~cm}$ pieces) (CODEX, 2009).

Fruits(raspberries, sourcherries, blackberries, cherries, strawberries) are commonly used, and in terms of physical means, the thermic ones (Vieru et al., 1974).

Marmalade is the finely ground pulp (the puree) obtained from apple, other fruit and sugar. Jam is a product made from fruit, whether alone or combined, and sugar or not, where the fruit does not remain whole.

At international level comfiture, non-gelled (without the addition of pectin from exogenous sources) is defined as "jam".

The traditional market in this field has been stable but it requires improvements (Miguel et al., 1999).

Classical but also improved technologies are used for its preparation. Especially for diversification another raw material is used, i.e. a combination of fruit and vegetables and more than one fruit (as this type of jam product is defined). 
Thus on the market there is a variety of jams made of: eggplant and cloves; chilli and ripe tomatoes; red onion; pumpkin and white sea buckthorn; beetroot; eggplant and coconut; pineapple and cucumber with sesame; olives and oranges; coconut, apple and celery (Whittingstall, 2011), carrot (Renna et al., 2013), sweet red pepper (Iancu et al., 2015). Apple, pumpkin and cinnamon are used for the new product proposed for the study.

Cinnamon belongs to the Lauraceae family, the Cinnamomum genus, the $C$. vertum species. It is the bark of the cinnamon tree originating in South East Asia. It is an ingredient recognized as safe for health according to the EO (Official Journal of the European Communities, 2002) and the US Food and Drug Administration, 2015. Cinnamon has strong antimicrobial and preservative activity (Soliman et al., 2002, Vidanagamagea, 2016). The impact of cinnamon oil on the sensory characteristics is strong (Ribes et al., 2017).

Cinnamon is rich in potassium, sodium, calcium, iron and magnesium, saturated, polyunsaturated, monounsaturated fats, carbohydrates, fibers, sugar, protein, vitamin $\mathrm{B}_{12}, \mathrm{~B}_{6}$ and vitamin $\mathrm{C}$ (Jakhetia et al. 2010).

As a consequence of its nutritional and functional properties, cinnamon is extensively used in the production of various foods, predominantly in the kitchen as a spice and a flavoring material. It is also used in various dessert recipes such as apple pie, donuts and cinnamon buns, spicy candy, tea, hot cocoa, liqueur, varieties of thick soups (Soliman et al., 2002), butter (Vidanagamagea, 2016).

It is recommended to use a cinnamon dose of $0-1.25 \mathrm{mg} / \mathrm{kg}$ (Banu et al., 1985). It is used in accordance with the current legal provisions as a safe food additive (Food and Drug Administration, 2015).

The pumpkin belongs to the Curcubita genus, the Curcubita maxima species. The fresh fruit is consumed for: joint pain (pumpkin milk), intestinal worms (seeds), inflammation of the prostate, cystitis, constipation, obesity, asthma, insomnia, it is antitumoral, it provides protection against cardiovascular diseases due to its antioxidant activity (Southon et al., 2002; Ziegler, 1989; Rao et al., 2007).

The pulp contains beta carotene (Chavasit et al., 2002; Gajc-Wolska et al., 2005; Murkovic et al., 2002), especially the winter type, namely: $\beta$-carotene $(>80 \%)$, lutein, lycopene, $\beta$-cryptoxanthin and $\alpha$-carotene (Rao et al., 2007), vitamins $\mathrm{E}, \mathrm{C}, \mathrm{B}_{6}, \mathrm{~K}$, thiamine, riboflavin, mineral salts(potassium, magnesium, selenium, phosphorus, iron), carbohydrates $(5.5 \mathrm{~g} / \mathrm{kg})$, proteins (1.1g/100g), water(91.3\%) (Radu, 1985).

However, the pumpkin has a poor taste and that is why it is commonly used in combination with something else.

The apple is part of the Rosaceae family, the Malus domestica genus. In the world fruit production, the apple tree occupies a special position, because together with the banana tree and the orange tree, it provides $2 / 3$ of the fruit harvest in the world (Ungureanu, 2006). The main apple-producing regions in Romania are located in the same area, namely in the sub-Carpathian hills, in the area of oak and beech forests. It is one of the most widely consumed fruits.

There are multiple options to store it over a long period of time. The main component of the apple tree fruit of technological importance is pectin (Vieru et al., 1981).

The main objective of this study is to comparatively analyze the main quality indicators for the apple, pumpkin and cinnamon jam with the values of products of the same category existing on the market or in the experimental stage.

The secondary objectives will be: the comparative analyses based on the sensory profile, establishing the proportions of the component materials (the recipe), the comparative analysis of the primary quality indicators required for including the new product on the profile market.

\section{MATERIALS AND METHODS Raw materials}

For the preparation of the product, the apple has been used, with the following characteristics: TSS $=12.66{ }^{\circ} \mathrm{Bx}$, titratable acidity $0.26[\%(\mathrm{w} / \mathrm{w})]$ expressed as malic acid, volatile acidity 0.023 $[\%(\mathrm{w} / \mathrm{w})]$ expressed in acetic acid, pumpkin with the specified characteristics: TSS $=4.65$ ${ }^{\circ} \mathrm{Bx}$, titratable acidity $0.18[\%(\mathrm{w} / \mathrm{w})]$ expressed as malic acid, volatile acidity $0.211[\%(\mathrm{w} / \mathrm{w})]$ expressed as acetic acid, cinnamon, sugar, citric acid and tap water. The apple and the pumpkin are from the sub-Carpathian area of Romania (Prahova and Vâlcea), marmalade (M) (artisanal production - Şura Mare - Sibiu - Romania); strawberry jam 
(JS), sweet cherry jam (JC)(commercial); red sweet pepper in vinegar jam(JPV), sweet red pepper roasted jam (JPR), sweet red pepper raw jam (JPRw) - another experiment (Iancu et al., 2016).

Jam making: (Recipe and manufacturing scheme) is done according to the operations presented and described in Tab. 1

Following this scheme in Tab. 1, apple jam (JA), pumpkin (JP) and apple, pumpkin and cinnamon jam (JAPC) were prepared. The samples were kept at a constant temperature of $20^{\circ} \mathrm{C}$. They were analyzed 2 weeks after preparation.

\section{METHODS OF PHYSICO-CHEMICAL ANALYSIS}

\section{Sensory evaluation of Jam}

The preparation of the aromatic profile was carried out in accordance with the literature (Poste et al., 1991). These components of the evaluated aromatic profile are: apple (A), pumpkin (P), bitter (B), caramel $(\mathrm{C})$, cinnamon $(\mathrm{Cn})$, raw pulp (RP), fruity (F), vanilla (V), sweet (Sw), residual (R). The sensory evaluation of the marmalade and the new product prepared from apple, pumpkin, cinnamon was made after discussion and training with a panel of 12 members, girls, with aged 19-20,

Tab. 1.Process for Jam, adaptation for the new product (Unido Technology Manual, 2004)

\begin{tabular}{|c|c|c|}
\hline \multirow[b]{2}{*}{$\begin{array}{l}\text { Stage and } \\
\text { process }\end{array}$} & \multicolumn{2}{|l|}{ Notes } \\
\hline & $\begin{array}{c}\text { Raw materials and } \\
\text { operations }\end{array}$ & Other materials \\
\hline Apple, pumpkin & $\begin{array}{l}\text { they are harvested at technological maturity, but not excessive, } \\
\text { free from } \\
\text { mold, } \\
\text { harvested so the pericarp not to be damaged }\end{array}$ & $\begin{array}{l}\text { Sugar, cinnamon water, } \\
\text { without preservative, } \\
\text { jars, caps }\end{array}$ \\
\hline $\begin{array}{l}\text { Reception } \\
\text { (inspect) }\end{array}$ & $\begin{array}{l}\text { at the reception, weigh and determine at the average sample, total } \\
\text { soluble substance content and acidity, in the lab }\end{array}$ & $\begin{array}{l}\text { Be appropriate in terms } \\
\text { of standards }\end{array}$ \\
\hline Sorted & $\begin{array}{l}\text { remove moldy fruits, rotten and damage, leaves stones, poor quality } \\
\text { raw materials, unsafe. }\end{array}$ & \\
\hline Wash & $\begin{array}{l}\text { is done using drinking water to remove possible contaminants such as } \\
\text { pesticide residues, insects, soil or dirt etc. }\end{array}$ & \\
\hline Sort-Grade & $\begin{array}{l}\text { done manually on a sorting table based on criteria: the degree of } \\
\text { maturity, shape and dimensions are not important }\end{array}$ & \\
\hline $\begin{array}{l}\text { Clean up } \\
\text { specific }\end{array}$ & $\begin{array}{l}\text { depending on the fruit, the peels are removed manually or } \\
\text { mechanically, as well as the seedling house of apples and the seeds and } \\
\text { the peel of the pumpkin }\end{array}$ & $\begin{array}{l}\text { Specific conditioning: } \\
\text { cinnamon grinding }\end{array}$ \\
\hline $\begin{array}{l}\text { Shredding } \\
\text { Division }\end{array}$ & $\begin{array}{l}\text { pulp thus obtained is divided into approximately pieces } \\
1.5 \mathrm{~cm} \text {, using manual or mechanized division }\end{array}$ & \\
\hline Mix & $\begin{array}{l}\text { adds approximately equal weight of sugar, at the weight of the solid } \\
\text { part of split apple pulp and pumpkin in a ratio of } 1: 1 \text {; the proportion of } \\
\text { sugar added is } 1: 1 \text { with the amount of TSS; syrup preparation: mix the } \\
\text { sugar with water(1:0,3) and boil to a content of } 60 \% \text { soluble dry } \\
\text { matter; cinnamom in the proportion of } 0.02 \% \text { is added at the end of } \\
\text { boiling. }\end{array}$ & \\
\hline Heat & $\begin{array}{l}\text { it is realizing at } 104-105^{\circ} \mathrm{C} \text { in a stainless steel vessel or to a } 63-70 \% \\
\text { soluble substance content, measured with a refractometer }\end{array}$ & \\
\hline Fill & $\begin{array}{l}\text { Filled in the pre-sterilized jars (boiled in water or in a oven at } 100^{\circ} \mathrm{C} \\
\text { for } 10-15 \text { minutes) }\end{array}$ & \\
\hline Seal & Are used to close caps for closing the twist-off, manual or mechanized. & \\
\hline $\begin{array}{c}\text { Advanced } \\
\text { pasteurization }\end{array}$ & $\begin{array}{l}\text { optional pasteurization is done according to scheme } \\
(15-20-15) / 90^{\circ} \mathrm{C}\end{array}$ & \\
\hline Cooling & at the room temperature, in the upright position & \\
\hline Storage & In a cold place and dry away from sunlight at constant temperature. & \\
\hline
\end{tabular}


students of the Faculty of Agricultural Sciences, Food Industry and Environmental Protection of ULB Sibiu, Romania and an industry participant (Canning factory from Rîureni, Vâlcea, Romania). The Panel assessed the presence and intensity of flavor components. To quantify the results was used a scale with values ranging from 1 (without the flavor component) to 5 (felt at maximum intensity). The reference was the panellists' experience, the aroma memorized from other apple, pumpkin and cinnamon products. Each panelist completed a questionnaire.

\section{Chemical analysis}

Determination of total soluble substances (TSS) [ ${ }^{\circ}$ Brix] (AOAC 932.12) (refractometer Krüss, Germany connected to a bathroom ultrathermostated Brookfield, Germany, with the outer circulation), titratable acidity $(\mathrm{TA})[\%(\mathrm{w} / \mathrm{w})]$, expressed as citric acid(AOAC 942.15); acidity volatile $[\%(\mathrm{w} / \mathrm{w})]$ expressed as acetic acid (AOAC method 964.08)(steam distillation apparatus, Alcotest Raypa, Spain), determination of the proportion of fruit in the Jam [\%], gravimetric determination using the technical balance (KERN $E G$, maxim $2200 \mathrm{~g}$, Germany). The reagents used for the analysis are of purity and the water used was distilled water.

\section{Statistical analysis}

Graphic interpretation and result processing were performed using the ORIGIN Pro-sofware analysis package. Interpretation of variance (ANOVA) was used to determine the significance level of the values of the determined quality indicators. For physicochemical determinations, 4 replicas were used.

\section{RESULTS AND DISCUSSION}

We shall further present the steps of the process of developing the new product obtained through an original combination of raw materials. The values of the quality indicators of the new product, the apple, pumpkin and cinnamon jam, are compared with the already existing assortments. The sugar preserved products covered by this study have been defined in the introduction section.

\section{The Comparative Analysis of the}

Assortments according to the Sensory

\section{Profile using PCA}

We conducted the sensory analysis of the products from which the research was initiated, namely M and JAPC. When analyzing the aromatic profile, the intensity of the flavor component was taken into consideration. Correlations were made between the values obtained in the aromatic profile, for 10 of its components, by 13 members of the panel. The scientific literature shows that the Principal Component Analysis (PCA) method is used to correlate the values of the analytically determined quality indicators (Renna et al., 2013) and espe-
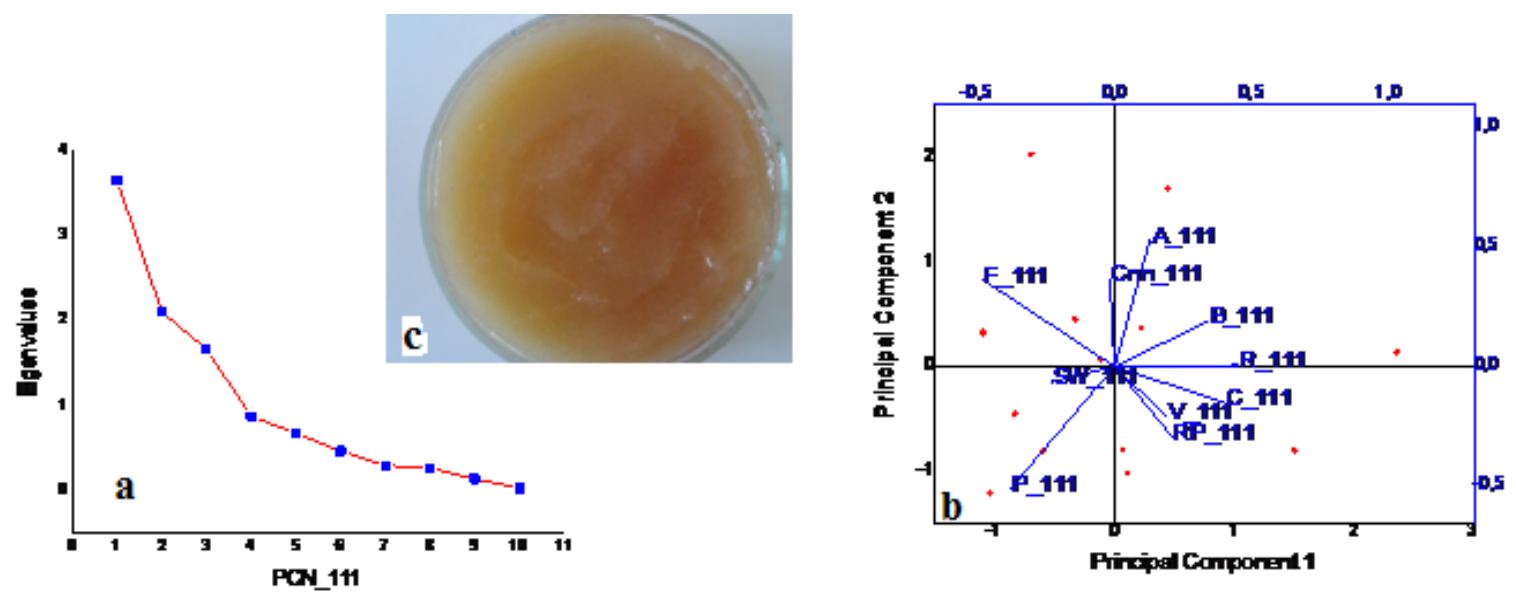

Fig. 1. a) Screen plot for the standardized variable (correlation matrix), b)Biplot of PCA , PCA1 and PCA2 for the sensory characteristics of the aromatic profile: A_111(apple); B_111(bitter), C_111(caramel); Cn_111(cinnamon); P_111(pumpkin); (F_111)(fruity); (V_111)(vanilla);(RP_111) (raw pulp); (Sw_111)(sweet);(R_111)(residual); c) Product picture apple, pumpkin and cinnamon marmalade(M)(111) 
cially in the sensory analysis for viewing the main analyzed components, the standardization and the influence of the values in Product quality profile (Liu et al., 2016). Figures 1a and 2a show that the typical values have a linear decrease.

The factors influencing the aromatic profile of the product are: the manufacturing recipe, the panelists' degree of subjectivity, and the number of determinations, 13. Each panelist should have provided the same answer. As this did not happen, the values of the volatile components from the aromatic profile analysis were reduced in number using the PCA. PC1 and PC2 (flavor component variables). It was determined which flavors are more similar. The volatile components are closely correlated with the sensory choice and variables such as: A_111, CRn_111, B_111 and R_111 are the components that significantly contribute to the intensity of the flavor for M. The values for C_111 and V_111 are very similar. The flavor component P_111 does not contribute at all to the creation of the flavor of the finished product. Figure 2 shows that the values for C_222; Cn_222; P_222; F_222; V_222; RP_222 are those that contribute to the intensity of the aromatic profile. A_222 is in the negative register, as well as B_222. All components contribute to the formation of the flavor in the case of the JAPC sample. The most significant is $\mathrm{Cn}$ (cinnamon), with positive implications.

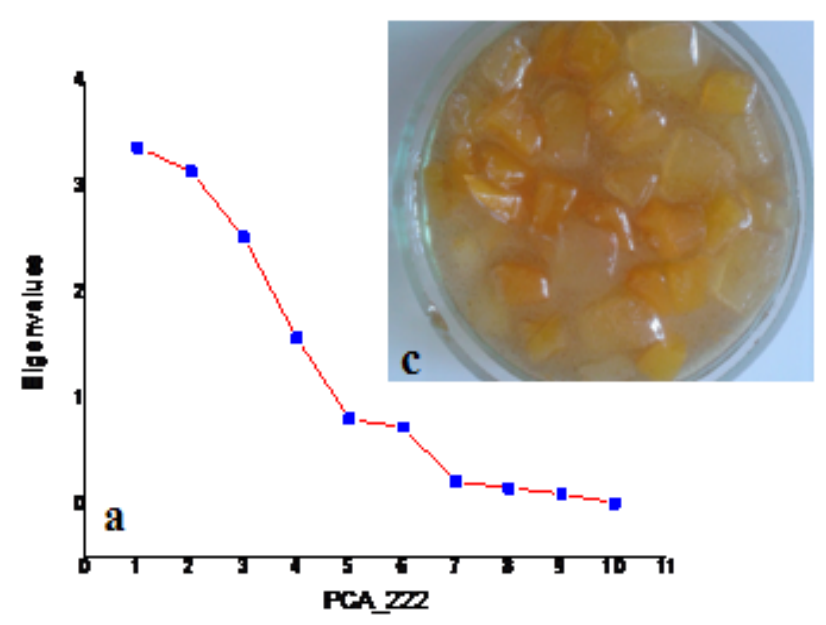

For the $M$ sample, the $A$ characteristic aroma is transmitted due to the presence of the components of the volatile fraction of apple such as ethyl propionate and butyl acetate which give the apple characteristic flavor (Lavilla et al., 1999). Hexylacetate gives the sweet fruit flavor and 1 butanol the honeyed flavor (Lavilla et al., 1999). At the JAPC sample, the aromatic characteristic of the product is associated with the presence of volatile components such as cinnamaldehyde, eugenol, trans-cinnamic acid (American Botanical Council, 2000; Engels et al., 2012). These components are very important for the specific flavor of the jam. Figures 1 and 2 clearly illustrate that flavor $\mathrm{F}$ is poorly represented at the taste level. For the JAPC sample, the flavor is somewhere at the middle of all values. It appears to be attenuated by the presence of pumpkin pulp that dilutes the specific flavor component of hexyl acetate. The selection of the volatile components is important for the sensory attributes of the new product. It is the first impact in the sensory evaluation of the panelist group. In accordance with the present study, the use of the screen plot for the standardized variables (correlation matrix) and biplot of PCA, PC1 and PC2 for the sensory characteristics of the aromatic profile is given by the presence of the flavor components from apple and cinnamon with positive correlations according to Figures 1

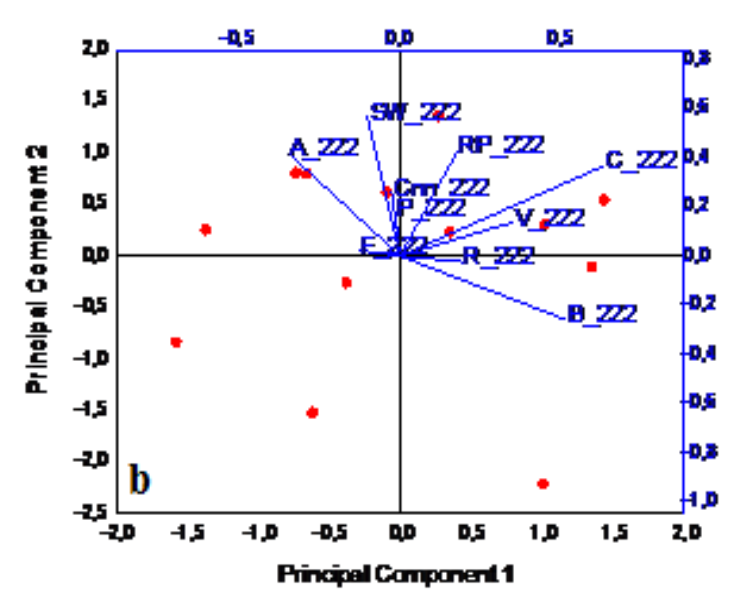

Fig. 2. a) Screen plot for the standardized variable (correlation matrix), b) Biplot of PCA, PCA1 and PCA2 for the sensory characteristics of the aromatic profile: A_222(apple); B_222(bitter), C_222 (caramel); Cn_222(cinnamon); P_222(pumpkin); (F_222)(fruity); (V_222)(vanilla);(RP_222) (raw pulp); (Sw_222)(sweet);(R_222)(residual); c) Product picture apple, pumpkin and cinnamon jam(JAPC)(222) 
and 2. The fruity and sweet aroma is associated with the recipe, therefore it is given by the sugar and the raw material, apple and pumpkin (less). The characteristic aroma is given to the jam from the apple and the cinnamon which contain flavor precursors such as: ethyl propionate $(120 \mu \mathrm{g} /$ $\mathrm{kg}$ ) and butyl acetate $(147.5 \mu \mathrm{g} / \mathrm{kg})$ which give the apple characteristic flavor. Hexyl acetate gives the sweet fruit flavor and 1-butanol the honeyed flavor (Lavilla et al., 1999).

\section{Establishing the Raw Material Proportions for JAPC}

The two jam assortments were prepared according to the technological scheme presented in table1. A difference was observed between the two assortments.

The most obvious was the consistency. It is known that the apple contains pectin (0.14$1.15 \%$ ) and therefore JA had a firm consistency due to the formation of the pectin gel even if jam is considered to be a non-gelled product. JP did not have a consistency comparable to that given by the apple. It was fluid, non-gelled, uninterruptedly flowing (Fig. 3-b). The solid part was floating in syrup at the organoleptic assessment. It has been concluded that it would be best to combine the two raw materials in a ratio of 1:1 in order to improve the characteristics of the finished product (consistency, color). At this stage cinnamon was not used.

Only this proportion variant has been studied. In the future, there will be other researches of other proportion variants. For the quantification of the consistency value, texture meters or consistency meters shall be used.

\section{The Physical-Chemical Analysis of the Jam} Samples

In order to determine the proportion of the solid part and the fraction of syrup, the jam samples that were prepared in the laboratory have been analyzed, as well as those obtained from the market, but not JA and JP.

The proportion of solid and liquid fraction for the JAPC sample is not comparable to commercial or craft production (Fig. 4). The amount of syrup is higher $(64 \%)$ than $55 \%$, maximum, as is the standard value, $45-55 \%$ (STAS 3750-90). Given the positive sensory assessment and the lack of "surface lifting" fault of the solid fraction, it is considered that the result can improve the database in the field.

The dry matter content (Fig. 5) has values that are standard for these products. It is a quality indicator of high technological and preservation importance. The sugar concentration changes and it gives a different content of dry matter. The higher the TSS, the higher the sucrose content. The value of $63.6^{\circ} \mathrm{Brix}$ in the JAPC sample ensures consistency and preservability of the new product, along with the effects of the pasteurization operation.

The dry substance of similar commercially available products (plums, strawberries, sour cherries) ranges from 35-65 ${ }^{\circ}$ Brix (Paladi et al., 2008 ) as well as the jam made of various mango varieties (Safdar et al., 2012).

The samples analyzed in this study have values of 70-72 ${ }^{\circ}$ Brix (commercially available), $62.9-67.4^{\circ}$ Brix (experimental pepper jam). A TSS value $<65^{\circ}$ Brix does not provide good long-term preservability without pasteurization (Table 1).

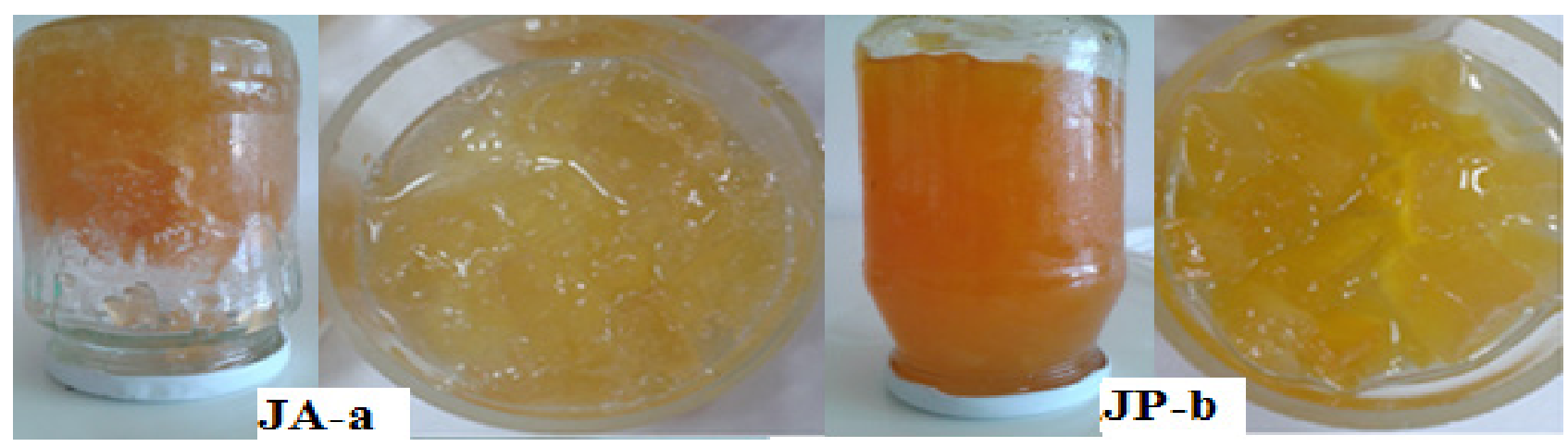

Fig. 3. Comparative presentation of the jam assortments of: apple-JA-a and pumpkin-JP-b; consistency of stored product revealed by image (the jar returned with 180 degrees) 


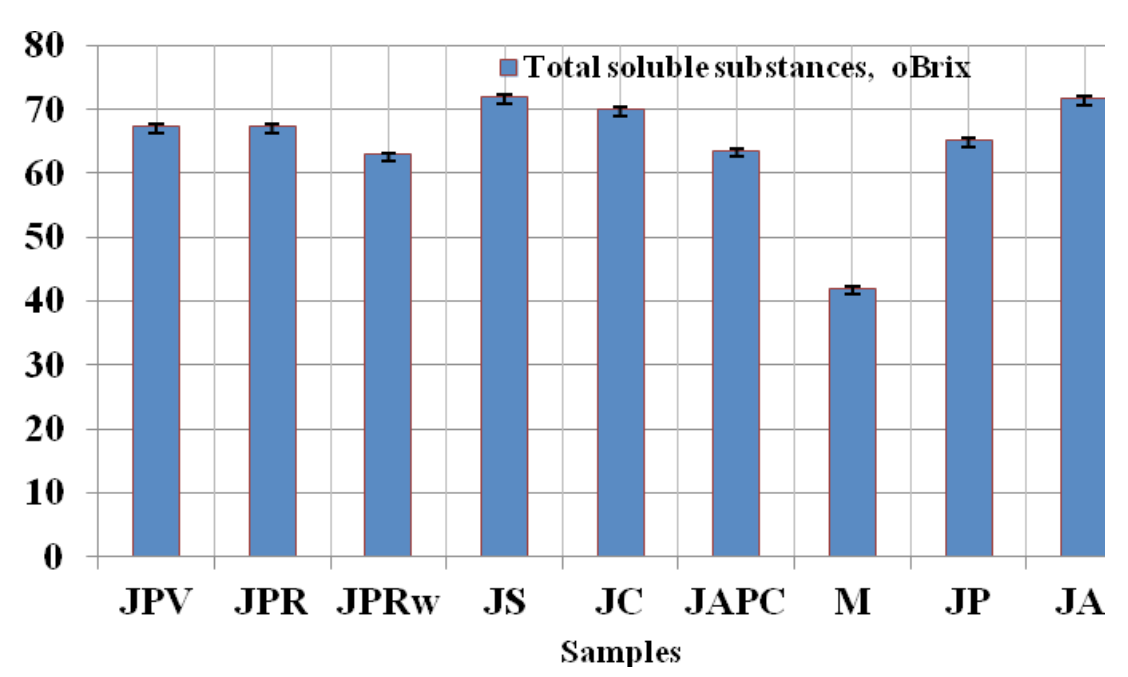

Fig. 4. Proportion of fractions: Solid (fruit) and liquid (syrup) in the jam samples (code-JPV, JPR, JPRw, JC, JS JAPC) analyzed. The vertical bars correspond to the standard deviation of the four determinations

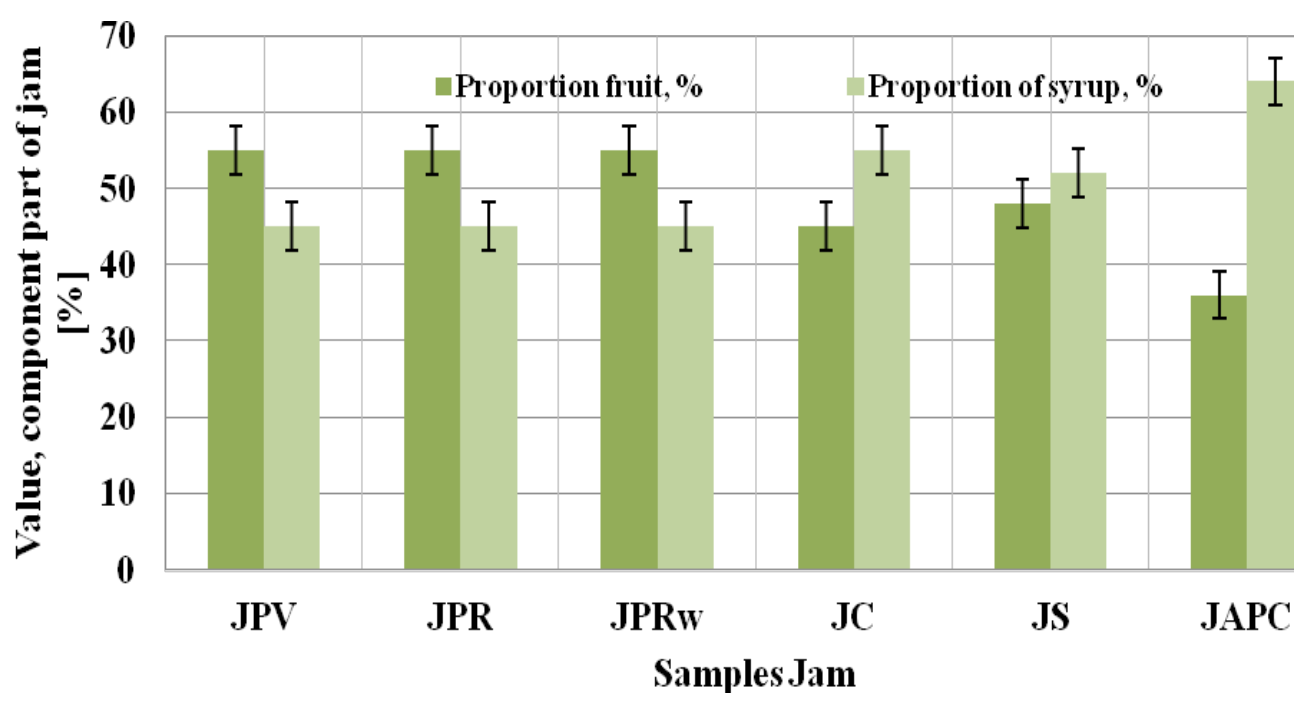

Fig. 5. Content of TSS in the jam samples (JPV, JPR, JPRw, JC, JS JAPC) and marmalade (M) analyzed. The vertical bars correspond to the standard deviation of the four determinations

The significance level for $\mathrm{n}=4$ is $\mathrm{p}<0,05$ (a-jam red pepper in vinegar, b-jam red pepper roasted, c-jam red pepper raw, d-strawberry jam, e-cherry jam, F-apple jam, g-pumpkin and cinnamon, marmalade; h-pumpkin jam, I- jam apple)

A comparative analysis of the value of the quality indicators from the primary analysis was carried out for several samples of jam. It was found that the values obtained for the total acidity range between 0.19-0.7 [\% (w/w)] (Table 2). The new product has a slightly lower value compared to the pepper jam values (Iancu et al., 2015) and to the commercial samples, JS and JC. The total acidity for the jam is generally $0.7 \%$ minus expressed as malic acid (STAS 3750-90). The acidity of the jam is given by the acidity precursors of the raw material, but also by the acid added in the recipe. The apple contains propionic acid, butyric acid, isovaleric acid, formic acid which contribute to the total acidity (Vieru, 1981). The components that contribute to the total and volatile acidity of JAPC given by cinnamon are: cinnamaldehyde, linalool, camphor, terpinen-4-ol and 1.8-cineol, eugenol, safrole, $\gamma$-muurolen, $\alpha$-cadinol, germacren $D$, 
Tab. 2. Total acidity [\% (w/w)] expressed as malic acid

\begin{tabular}{|c|c|c|c|c|c|c|}
\hline \multirow{2}{*}{ The sample code } & \multirow{2}{*}{$\begin{array}{l}\text { Mean } \\
\text { value }\end{array}$} & \multirow{2}{*}{$\begin{array}{l}\text { Standard } \\
\text { Deviation }\end{array}$} & \multirow{2}{*}{ Sum } & \multicolumn{3}{|c|}{ Range } \\
\hline & & & & Minim & Median & Maximum \\
\hline $\mathrm{JPV}^{\mathrm{a}}$ & 0.43 & 0.0526 & 1.7 & 0.38 & 0.41 & 0.5 \\
\hline $\mathrm{JPR}^{\mathrm{b}}$ & 0.11 & 0.01826 & 0.44 & 0.09 & 0.11 & 0.13 \\
\hline$J R^{c} W$ & 0.30 & 0.01916 & 1.209 & 0.289 & 0.295 & 0.33 \\
\hline $\mathrm{JS}^{\mathrm{d}}$ & 0.66 & 0.03594 & 2.61 & 0.6 & 0.666 & 0.68 \\
\hline $\mathrm{JC}^{\mathrm{e}}$ & 0.7 & 0.01291 & 2.82 & 0.69 & 0.705 & 0.72 \\
\hline JAPC $^{\mathrm{f}}$ & 0.2 & 0.01013 & 0.828 & 0.198 & 0.205 & 0.22 \\
\hline $\mathrm{M}^{\mathrm{g}}$ & 0.5 & 0.01018 & 1.981 & 0.48 & 0.5 & 0.501 \\
\hline$J P^{h}$ & 0.2 & 0.02217 & 0.83 & 0.19 & 0.2 & 0.24 \\
\hline$J A^{i}$ & 0.19 & 0.00661 & 0.786 & 0.19 & 0.196 & 0.204 \\
\hline
\end{tabular}

Tab. 3. Volatile acidity [\% (w/w)] expressed as acetic acid

\begin{tabular}{|c|c|c|c|c|c|c|}
\hline \multirow{2}{*}{ The sample code } & \multirow{2}{*}{$\begin{array}{l}\text { Mean } \\
\text { value }\end{array}$} & \multirow{2}{*}{$\begin{array}{l}\text { Standard } \\
\text { Deviation }\end{array}$} & \multirow{2}{*}{ Sum } & \multicolumn{3}{|c|}{ Range } \\
\hline & & & & Minim & Median & Maximum \\
\hline $\mathrm{JPV}^{\mathrm{a}}$ & 0.24 & 0.14271 & 0.969 & 0.029 & 0.305 & 0.33 \\
\hline $\mathrm{JPR}^{\mathrm{b}}$ & 0.022 & 0.00171 & 0.087 & 0.02 & 0.0215 & 0.024 \\
\hline$J_{P R}{ }^{\mathrm{W}}$ & 0.020 & 0.00171 & 0.083 & 0.019 & 0.0205 & 0.023 \\
\hline$J S^{\mathrm{d}}$ & 0.044 & 0.00954 & 0.177 & 0.03 & 0.0485 & 0.05 \\
\hline $\mathrm{JC}^{\mathrm{e}}$ & 0.077 & 0.04468 & 0.308 & 0.01 & 0.099 & 0.1 \\
\hline $\mathrm{JAPC}^{\mathrm{f}}$ & 0.105 & 0.01 & 0.42 & 0.1 & 0.1 & 0.12 \\
\hline $\mathrm{M}^{\mathrm{g}}$ & 0.09 & 0.00957 & 0.39 & 0.09 & 0.095 & 0.11 \\
\hline$J P^{h}$ & 0.017 & 0.00486 & 0.069 & 0.01 & 0.0195 & 0.02 \\
\hline$J A^{i}$ & 0.07 & 0.00126 & 0.281 & 0.069 & 0.07 & 0.072 \\
\hline
\end{tabular}

$\alpha$-terpineol, 3-ol, 3.7-dimethyl and 1-phenylpropane - 2.2 - diol diethanoate (Jantan, 1990, 1992; Jantan et al., 2003; Rana et al., 2009; Abdelwahab et al., 2010; Geng et al., 2011). It is noticeable that they also influence the aroma profile of the newly created product (see the comparative analysis of the assortments based on the sensory profile). The pumpkin is more a source of protein and fiber. The above-mentioned apple components also make their contribution. In this case, in order to increase the acidity of JAPC, it is necessary to supplement the recipe with citric acid which will balance the acidic component to a value of $0.7[\%(\mathrm{w} / \mathrm{w})]$.

Consistent with the values presented in table 3 for the volatile acidity, it is observed that in the
JAPC sample the mean value is higher. This value of $0.105[\%(\mathrm{w} / \mathrm{w})]$ expressed in acetic acid, however, is higher due to the presence of cinnamon and its volatile components which have also influenced the aromatic profile of the product.

The significance level for $n=4$ is $p<0,05$ (a-jam red pepper in vinegar, b-jam red pepper roasted, c-jam red pepper raw, d-strawberry jam, e-cherry jam, F-apple jam, g-pumpkin and cinnamon, marmalade; h-pumpkin jam, I- jam apple)

The volatile acidity of the jam is given by the acid fractions of the components obtained by steam distillation and which contribute to the formation of the aromatic profile. The flavor components were used to explain the aromatic profile. The 
official standard does not present values of this quality indicator. However, it is considered that this study can complete the database in this respect. The volatile acidity is a measure of the flavor components. The value of $0.105[\%(\mathrm{w} / \mathrm{w})]$ of the newly created JAPC that is well above the values of other established assortments stands proof of that fact.

\section{CONCLUSION}

The overall conclusions of this study are that all the initially set objectives were completed. Thus: the proportion of raw materials apple and pumpkin was well chosen in a ratio of $1: 1$ because they mutually improve their characteristics, the apple contributes to the increase of consistency and flavor and the pumpkin to the fineness of texture and color; the combination of pumpkin and apple improves the characteristics of the jam given by the raw material if these plants had been used separately; cinnamon, through the cinnamic aldehyde complements and individualizes the aroma profile of the product very well, and the use of PCA has helped to simplify the results; the values of the quality indicators analyzed for the newly created product generally fall within the standards for trade and experimental jam; by studying these parameters, the recipe, the proportion of fruit in the solid part, and the amount of acid added from natural sources can be improved, and the higher acidity will better emphasize the aroma profile of the newly created product.

\section{REFERENCES}

1. Abdelwahab SI, Faridah QZ, Mariod AA,Yacoob M, Abdelmageed AHA, Khamis S (2010). Chemical composition, antioxidant and antibacterial properties of the essential oils of Etlingera elatior and Cinnamomum pubescens Kochummen. J. Sci. Food Agric., 90:2682-2688.

2. American Botanical Council (2000). Herbal Medicine: Expanded Commission E Monographs. Newton, MA: Integrative Medicine Communications.

3. A.O.A.C 17th ed. (2000). Official method 942.15 Acidity (Titratable) of fruit products read with A.O.A.C official method 920.149, Preparation of test sample.

4. A.O.A.C 17th ed. (2000). Official method 925.34, Acidity(Volatile) of fruit products, Steam Distillation method with A.O.A.C official method 964.08 acidity (Total Volatile) of wines.

5. A.O.A.C. (1980). Official Method 932.12, Solids (Soluble) in Fruits and Fruit Products Refractometer Method. Fruit and Vegetable Products.
6. Banu C. Cooord., Vasu SS, Dima D, Preda N, Giurcă V, Enache A, Bordei D, Stoicescu A, Rotaru G, Ana A, Eniceicu A, Oprea A, Grigore Ș, Desa A (1985). Folosirea Aditivilor în Industria Alimentară, Editura Tehnică București.

7. Chavasit V, Pisaphab R, Sungpuag P, Jittinandana S, Wasantwisut E (2002). Changes in $\beta$-carotene and vitamin A content of vitamin A-rich foods in Thailand during preservation and storage. Journal of Food Science, 67:375-379.

8. CODEX STAN 296-2009, Codex standard for Jam, Jellies and Marmlades.

9. Engels G, Brinckmann J (2012). Cinnamon. HerbalGram. The Journal of the American Botanical Council, (95):1-5, http://cms.herbalgram.org.

10. Food and Drug Administration (2015). Substances generally regarded assafe. Spices and other natural seasonings and flavorings. USDepartment of Health and Human Services. 21CFR182.10. https://www.accessdata. fda.gov/scripts/cdrh/cfdocs/cfcfr/.

11. Gajc-Wolska J, Gajewski M, Radzanowska J, NiemirowiczSzczytt K, Korzeniewska A (2005). The fruit quality assessment of the chosen hybrids and cultivars of pumpkin (Cucurbita maxima Duch.). Vegetable Crops Research Bulletin, 63:33-43.

12. Geng S, Cui Z, Huang X, Chen Y, Xu D, Xiong P (2011). Variations in essential oil yield and composition during Cinnamomum cassia bark growth. Ind. Crops Prod., (33):248-252.

13. Gruenwald J, Freder J, Armbruester N (2010). Cinnamon and health. Crit Rev Food Sci Nutr, 50(9):822-834.

14. Iancu ML, Benea D D, Benea L, Maier AM (2015). New Usage of Capsicum (Capsicum annuum) in the Food Industry. Sweet Products. Journal of Agroalimentary Processes and Technologies, 21(2):162-172, http:// journalof agroalimentary.ro.

15. Jakhetia V, Patel R, Khatri P, Pahuj N, Garg S, Pandey A, Sharma S (2010). Cinnamon: A Pharmacological Review. Journal of Advanced Scientific Research, 1(2):19-23.

16. Jantan I, Goh SH (1990). The essential oils of Cinnamomum mollissimum as natural sources of safrole and benzyl benzoate. J. Trop. Forest Sci., 2(3):252-259.

17. Jantan I, Goh SH (1992). Essential oils of Cinnamomum species from Peninsular Malaysia. J. Essent. Oils Res., 4,161-171.

18. Jantan EL, Yeoh, S, Romli N, Ayop AS (2003). Comparative study of the constituents of the essential oils of three Cinnamomum species from Malaysia. J. Essent. Oil Res., 51:3887-391.

19. Lavilla T, Puy J, Lopez ML, Recasens I, Vendrell M (1999). Relationships between volatile production, fruit quality and sensory evaluation in Granny Smith apples stored in different controlled atmosphere treatments by means of multivariate analysis. J Agric Food Chem, 47:3791-3803.

20. Liu L, Ji ML, Chen M, Sun M, Fu XL, Li L, Gao DS, Zhu CY (2016). The flavour and nutritional characteristic of four strawberry varieties cultured in soilless system. Food Science Nutrition, 4(6):858-868, doi: 10.1002/fsn3.346. 
21. Miguel GN, Belloso MO (1999). Influence of fruit dietary fibre addition on physical and sensorial properties of strawberry jams. Journal of Food Engineering, 41:13-21.

22. Murkovic M, Muelleder U, Neunteufl H.(2002). Carotenoid content in different varieties of pumpkins. Journal of Food Composition and Analysis, 15:633-638.

23. Official Journal of the European Communities (2002). Commission Decision of 23, January 2002 amending Commission Decision 1999/217/EC as regards of flavouring, used in or on foodstuffs (notified under document number C, 88, (2002/113/EC).

24. Poste ML, Deborah I, Mackie A,Gail Butler I, Larmond GE (1991). Laboratory methods for sensory analysis of food. Research Branch Agriculture Canada Publication 1864/E 1991.

25. Paladi D, Tatarov P (2008). Physical Chemical characteristics of the taste of jam type products, The Annals of the University Dunărea de Jos of Galați. Fascicle VI- Food Technology, New Series XXXI(2): 66-70.

26. Radu IF (1985). Tratat de Tehnologie a fructelor și legumelor Volumul I, Fructe și legume ca materie primă Editura Scrisul Românesc, Craiova.

27. Rana VS, Devi CB, Verdeguer N, Blazquesz MA (2009). Variation of Terpenoids constituents in natural population of Cinnamomum tamla (L.) leaves. J. Essent. Oils Res., 21:531-534

28. Rao AV, Rao LG (2007). Carotenoids and human health. Pharmacological Research, 55: 207-216.

29. Renna M, Pace B, Cefola M, Santamaria P, Serio F, Gonn Mella M (2013). Comparison of two jam making methods to preserve the quality of colored carrots. LWT - Food Science and Technology, 53:547-554, http://dx.doi. org/10.1016/Jwt.2013.03.018.

30. Ribes S, Fuentes A, Talens P, Barat JM (2017). Application of cinnamon bark emulsions to protect strawberry jam from fungi. LWT - Food Science and Technology, 78:265272.

31. Safdar MN, Mumtaz A, Hameed T, Siddiqui N, Khalil S, Amjad M (2012). Storage Studies of Jam Prepared from Different Mango Varieties, Pakistan Journal of Nutritions 11(7):555-561.
32. Soliman KM, Badeaa RI (2002). Effect of oil extracted from some medicinal plants on different mycotoxigenic fungi. Food Chem. Toxicol, 40:1669-1675.

33. Southon S, Faulks R (2002). Health benefits of increased fruit and vegetable consumption. In W. Jongen (Ed.), Fruit and vegetable processing (5-21), Cambridge: Woodhead Publishing Ltd.

34. STAS 3750-90, Dulceața, www. Asro.ro.

35. Ungureanu TCC (2006). Contribuții la studiul biologiei, ecologiei și combaterii integrate a principalilor dăunători din plantațiile de măr din judetul Botoșani, Rezumatul tezei de doctorat, Iași.

36. Unido technology manual (2004). Small-scale Fruit and Vegetable Processing and Products Production methods, equipment and quality assurance practices, United Nations Industrial Development Organization, Vienna, economy environment employment (https://www.unido. org/ fileadmin/ user_media/Publications/Pub_ free/ Small)

37. Vidanagamagea SA, Pathirajea PMHD, Pereraa ODAN (2016). Effects of Cinnamon (Cinnamomum verum) extract on functional properties of butter, Procedia Food Science, 6:136 -142, doi: 10.1016/j.profoo.2016.02.033.

38. Vieru R, Băltărescu S (1974). Tehnologia dulcețutilor, gemurilor,siropurilor și jeleurilor, redacția Revistei Agricole, București.

39. Vieru R, Ceușescu M, Bacheș E, Băltărescu S (1981). Cartea preparatorului de conserve din fructe, Editura Tehnică, București.

40. Whittingstall FH (2011). Vegetable jam recipes Food and drink, Hugh Fearnley-Whittingstall recipes, Friday, January 2, http://www.theguardian.com/ lifeandstyle/2011/sep/02/ vegetable-jam-recipeshughfearnley-whittingstall

41. Yahia EM (2010). The contribution of fruits and vegetable consumption to human health. In De la Rosa LA, ÁlvarezParilla E, \& González-Aguilar GA (Eds.). Fruit and vegetable phytochemicals Iowa: Wiley-Blackwell, 3-51.

42. Ziegler RG (1989). A review of epidemiologic evidence that carotenoids reduce the risk of cancer. Journal of Nutrition, 119:116-122. 